\title{
RESPONSE OF POTTING MIXTURES AGAINST GROWTH AND FLOWERING OF
}

\section{CHRYSANTHEMUM CV. HALDIGHATI}

\section{MONIKA, KULVEER SINGH YADAV \& ANKUSH CHANDLA}

School of Agricultural Sciences and Technology, RIMT University, Mandi Gobindgarh, Punjab, India

\begin{abstract}
To study the effect of different potting mixtures on growth and flowering of chrysanthemum cv. Haldighati a pot experiment was conducted at Agriculture Farm, School of Agricultural Sciences \& Technology, RIMT University, Mandi Gobindgarh, Punjab, India during 2019. The experiment was laid out in completely randomized block design along with three replications. The different treatments included the combinations of sand, soil, coco peat, vermicompost, farm yard manure, perlite in equivalent ratio. The results revealed that the overall performance of chrysanthemum was better in media having $T_{7}$ i.e. Perlite + FYM + Garden soil (2:1:1) except $T_{5}$ i.e. Vermicompost + FYM + Garden soil (2:1:1) were recorded the highest number of main and sub branches per plant, number of ray florets per flower, length and width of ray florets. On the basis of result obtained it is concluded that potting media treatment combination consisting from Perlite + FYM + Garden soil (2:1:1) were found best for pot mum chrysanthemum production over treatments.

KEY WORDS: Potting Mixture, Production, Vermicompost, Perlite and Chrysanthemum
\end{abstract}

Received: Jan 15, 2021; Accepted: Feb 05, 2021; Published: Mar 02, 2021; Paper Id.: IJASRAPR20213

\section{INTRODUCTION}

Chrysanthemum (Dendranthema grandiflora) is a valuable commercial flower crop, belongs to Asteraceae family and grown for its attractive flowers in all over the world. Chrysanthemum is a perennial herbaceous plant that is widely cultivated throughout the world for its lovely flowers with excellent vase life. Chrysanthemum is one of the important species of ornamental plants in which it has a high economic value, either in the form of cut flowers and pot plants. The demand for chrysanthemum is increasing, especially on religious holidays such as Christmas, New Years and Valentine's (Warnita et al., 2017). Potted chrysanthemums or potted mums are popular choices for beautifying living spaces, balconies and terraces. Chrysanthemum may also be used in pot mums, bedding, border plant and hanging baskets (Raj, 2015). Demand of chrysanthemum flowers in India exists in big metropolitan cities like Delhi, Calcutta, Mumbai, Bangalore, Coimbatore etc. (Kumar et al., 2014). Pot mums occupy an important place in the European, North American and Japanese floriculture trade. The major producing countries are Germany, Italy, Poland, Hungary and Russia. The Netherland and Columbia are the main exporters of chrysanthemum (Nair and Bharathi, 2015).

Chrysanthemum cultivation has grown in various Indonesian production centres as a profitable source of income for farmers. Nowadays, because it is easy to move and display during exhibitions and flower shows, ornamental pots raised in light potting media have been found to be more ideal choices (Dubey et al., 2013). The potting medium is one of the most important factors needed to produce high-quality pots. It is known that the 
growth medium has the value of potted ornamental plants and plays an important role in the germination rate and many other physiological parameters including plant height, leaf number, spike length, number of florets per spike, spike diameter and yield etc (Ikram et al., 2012). Choosing a good medium should be used as storage for plant nutrients, to provide support for plant growth, provide water for plants, and promote gas exchange between the root system and the atmosphere above the root system. When the best growth medium is used in conjunction with a substrate with less soil, it should have proper aeration, water retention capacity and sufficient nutrient supply (Khobragade et al., 1997).

Coco peat is an organic by-product of the coconut husk industry. It is obtained by extracting fibre from coconut husk. Coco peat is light in weight, low shrinkage, low bulk density, slow biodegradation and longer decomposition time (10 years). The coco peat can be effectively recovered and has an acceptable $\mathrm{pH}$ (5.2-6.8) (Evans et al., 1996). Coco peat contains soluble salts of chloride and sodium as well as higher contents of potash. Vermicompost is also known as worm casting, worm humus or worm fertilizer and the end product of decomposing organic matter. This compost is an odourless, clean organic material, which contains sufficient amounts of N, P, K and several micronutrients necessary for plant growth. Perlite is a siliceous mineral derived from volcanic rocks. First crush the grades used in the container medium, and then heat until the combined water vaporizes and expands into a light powdery substance. The lightness and uniformity of perlite is very useful for increasing aeration and drainage. Cattle manure is a waste fertilizer of cattle farms, which plays a role in improving soil physical properties and enriching soil nutrients (Situmeang et al., 2017).

\section{MATERIALS AND METHODS}

The investigation was carried out during the year 2019 at Agriculture Farm, School of Agricultural Sciences and Technology, RIMT University, Mandi Gobindgarh, Punjab. A pot experiment was conducted to determine the effect of different potting mixtures on the growth and flowering of chrysanthemum cv. Haldighati. The experiment consist of seven treatments viz. Garden Soil : Control $\left(T_{1}\right)$, Coco peat + Garden soil $(1: 1)\left(T_{2}\right)$, Coco peat + FYM + Garden Soil (2:1:1) $\left(\mathrm{T}_{3}\right)$, Vermicompost + Garden Soil (1:1) $\left(\mathrm{T}_{4}\right)$, Vermicompost + FYM + Garden soil (2:1:1) $\left(\mathrm{T}_{5}\right)$, Perlite + Garden soil (1:1) $\left(\mathrm{T}_{6}\right)$, Coco peat Perlite + FYM + Garden soil $(2: 1: 1)\left(\mathrm{T}_{7}\right)$ in a Completely Randomized Design (CRD) with three replications. Potting mixture is prepared by using different media like coco peat, vermicompost, perlite, garden soil and farm yard manure. All the experimental pots have been filled with different type of media according to the treatments. The size of the pot used in this experiment was 12 inches. The total number of pots in the experiment is 21 . Before filling the potting medium, thoroughly wash and clean the pot. According to the treatment method, 21 pots were filled with the required potting medium. Mix the potting media used for other treatments in the same way and complete the potting. The 5-7 cm long cuttings are taken from healthy original plants of Lucknow CSIR-NBRI. Healthy cuttings were planted in the pots and gently spray the water with the help of rose can. Three equally spaced plants were kept in one pot in one replication. Frequent irrigation is required for proper growth of the plant. Observe the plants every day and water them manually with a hand sprinkler when needed. The chrysanthemum plants were pinched one month after planting in order to break their apical dominance to increase their lateral spread. Weeding was done as and when required to keep the crop free from weeds. The data on various vegetative characters and floral characters were recorded and statistically analysed. The qualitative parameters characters were analyzed by the analysis of variance (ANOVA) technique. The data was subjected to statistical analysis adopting the standard procedure as laid down by Panse and Sukhatme (1964). The critical difference values were calculated at 1 percent level of significance. 


\section{RESULT AND DISCUSSION}

\section{Growth Parameters}

Data on growth is presented in Table 1. Treatment $\mathrm{T}_{7}$ (Perlite $+\mathrm{FYM}+$ Garden soil (2:1:1)) resulted maximum stem diameter $(0.43 \mathrm{~cm})$ was recorded with the treatment followed by $\mathrm{T}_{5}(0.37 \mathrm{~cm}), \mathrm{T}_{6}(0.34 \mathrm{~cm})$ and $\mathrm{T}_{3}(0.32 \mathrm{~cm})$, whereas, the minimum stem diameter $(0.18 \mathrm{~cm})$ was recorded under $\mathrm{T}_{2}$ (Coco peat + Garden Soil (1:1)). These results corroborate the findings of Mehwish et al (2007) in dahlia and Talukdar et al (2003) in chrysanthemum was reported maximum stem diameter with growing media combinations sand + silt + leaf. This is because the growing medium can improve proper aeration, water retention, and absorb a large amount of nutrients through the roots, thereby converting them into photosynthetic products, helping cell division, and cell elongation resulting in a larger stem diameter. The highest plant spread $(12.80 \mathrm{~cm})$ was recorded with the treatment $\mathrm{T}_{7}$ i.e. Perlite $+\mathrm{FYM}+$ Garden soil $(2: 1: 1)$ followed by $\mathrm{T}_{5}(12.23 \mathrm{~cm})$, $\mathrm{T}_{3}(12.13 \mathrm{~cm})$ and $\mathrm{T}_{4}(10.44 \mathrm{~cm})$. While the lesser plant spread $(8.30 \mathrm{~cm})$ was noticed under $\mathrm{T}_{1}$ (control). The results are supported by the findings of Turhan et al (2007) in saffron, Gohil et al (2018) in chrysanthemum and Naggar and Nasharty (2009) in Hippeastrum vittatum who indicated that the maximum plant spread was obtained in media containing sand + poultry manure. The greater fresh weight of leaf $(0.41 \mathrm{~g})$ was recorded with the treatment $\mathrm{T}_{7}$ (Perlite $+\mathrm{FYM}+$ Garden soil (2:1:1)) followed by $\mathrm{T}_{5}(0.28 \mathrm{~g}), \mathrm{T}_{3}(0.20 \mathrm{~g})$ and $\mathrm{T}_{6}(0.18 \mathrm{~g})$, the lowest fresh weight of leaf $(0.10 \mathrm{~g})$ was found under $\mathrm{T}_{4}$ (Vermicompost + Garden Soil (1:1)). This is in accordance with the findings of Nazari et al (2011) in hyacinth and Gohil et al (2018) in chrysanthemum, who had reported highest fresh weight of leaf in media containing coco peat combined with soil. The maximum leaf biomass $(6.70 \mathrm{~g})$ was recorded with the treatment $\mathrm{T}_{7}$ (Perlite + FYM + Garden soil (2:1:1)) followed by $\mathrm{T}_{5}(4.86 \mathrm{~g}), \mathrm{T}_{3}(4.34 \mathrm{~g})$ and $\mathrm{T}_{6}(3.34 \mathrm{~g})$ while, the least leaf biomass (2.10) was reported under $\mathrm{T}_{1}$ (control). This result also supported by the findings of Jin et al (2002) in lily and Pal and Biswas (2005) in tuberose. They observed that composted rice husk + sawdust + pine bark (1:1:1) is a more suitable medium for producing the highest leaf biomass. The maximum number of suckers per plant (2.44) were counted under $\mathrm{T}_{7}$ (Perlite + FYM + Garden soil (2:1:1)) followed by $T_{5}$ (2.11), $T_{3}$ (1.55) and $T_{6}$ (1.00) while the less number of suckers per plant (0.44) were recorded under $T_{1}$ (control). Present findings get support from the work done by Barreto and Jagtap (2006) and Singh (2018) in gerbera, who reported highest number of suckers with media containing in coir pith + vermicompost.

\section{Flowering Parameters}

Data about flowering is cited in Table 2. The minimum duration was observed for first colour shown (52.33 days) with the treatment $\mathrm{T}_{7}$ (Perlite $+\mathrm{FYM}+$ Garden soil (2:1:1)) followed by $\mathrm{T}_{5}$ (53.59 days), $\mathrm{T}_{3}$ (53.70 days) and $\mathrm{T}_{6}$ (64.44 days) while, the maximum days to first colour shown (70.92 days) was recorded under $\mathrm{T}_{1}$ (control). These results are in accordance with the findings of Chauhan et al (2014), Singh (2018) in gerbera and Karthikeyan and Jawaharlal (2015) in carnation, who recorded minimum days to first colour shown in Coir pith + Vermicompost media combinations. Treatment $\mathrm{T}_{7}$ (Perlite + FYM + Garden soil (2:1:1)) was reported with the highest flower diameter $(3.24 \mathrm{~cm})$ and it was closely followed by $\mathrm{T}_{5}$ $(2.89 \mathrm{~cm}), \mathrm{T}_{3}(2.78 \mathrm{~cm})$ and $\mathrm{T}_{6}(2.64 \mathrm{~cm})$ while, the lowest flower diameter $(1.95 \mathrm{~cm})$ was found under $\mathrm{T}_{1}$ (control). This result agrees with the finding of Younis et al (2008) in dahlia, Barman et al (2006) in rose and Yasmeen et al (2012) in Carnation. They stated that maximum values for number of flowers of were obtained when soil + coco peat + leaf manure was used. This is due to the fact that excess food reserves are only transferred to fewer sinks (flowers), thus producing larger flowers. Treatment $T_{5}$ (Vermicompost + FYM + Garden soil (2:1:1)) was noticed with maximum number of ray florets per flower (83.55) followed by $\mathrm{T}_{7}$ (82.92), $\mathrm{T}_{3}$ (82.59) and $\mathrm{T}_{6}$ (78.39). While, the minimum number of ray florets per flower (74.55) was counted under $\mathrm{T}_{1}$ (control). Present findings are in accordance with the findings of Nowak and Strojny 
(2004) in gerbera, Bhatia et al (2004) in Carnation and Rani et al (2005) in lillium, who recorded maximum number of ray florets with media soil + sand + municipal waste compost. The longest length of ray florets $(2.57 \mathrm{~cm})$ was recorded with the treatment $\mathrm{T}_{5}$ (Vermicompost + FYM + Garden soil (2:1:1)) followed by $\mathrm{T}_{7}(2.47 \mathrm{~cm}), \mathrm{T}_{3}(2.38 \mathrm{~cm})$ and $\mathrm{T}_{6}(2.31 \mathrm{~cm})$ while, the shortest length of ray florets $\left(2.11 \mathrm{~cm}\right.$ ) was reported under $T_{1}$ (control). This result agrees with the finding of Yasmeen et al (2012) in carnation and Barreto and Jagtap (2006) who had recorded maximum length of ray florets with soil + coco peat + leaf mould media combination. Treatment $T_{5}$ (Vermicompost + FYM + Garden soil (2:1:1)) resulted wider width of ray florets $(0.53 \mathrm{~cm})$ and it was followed by $\mathrm{T}_{7}(0.50 \mathrm{~cm}), \mathrm{T}_{3}(0.48 \mathrm{~cm})$ and $\mathrm{T}_{6}(0.46 \mathrm{~cm})$. Nevertheless, the narrowest width of ray florets $(0.40 \mathrm{~cm})$ was recorded under $\mathrm{T}_{1}$ (control). These results are supported with the findings Barman et al (2006) in rose and Yasmeen et al (2012) in carnation, who reported that highest width of ray florets in media containing soil + coco peat + leaf mould. Maximum peduncle length $(4.94 \mathrm{~cm})$ was measured under $\mathrm{T}_{7}($ Perlite $+\mathrm{FYM}+$ Garden soil (2:1:1)) followed by $\mathrm{T}_{5}(4.66 \mathrm{~cm}), \mathrm{T}_{3}(3.95 \mathrm{~cm})$ and $\mathrm{T}_{6}(3.72 \mathrm{~cm})$. While, $\mathrm{T}_{1}$ (control) reported for the minimum peduncle length $(2.44 \mathrm{~cm})$. Present findings of flowering are in accordance with the findings of Shammy et al (2012) in gerbera and Mohapatra et al (2000) in chrysanthemum was reported maximum peduncle length with media containing sandy soil and cow dung.

\section{CONCLUSIONS}

Therefore, it can be concluded that using vermicompost and perlite together with FYM helps to achieve better plant growth and better chrysanthemum flower quality.

\section{REFERENCES}

1. Barman, D., Rajni, K., Upadhyaya, R. C., and Singh, D. K. (2006). Effect of horticultural practices for sustainable production of rose in partially modified greenhouse. Indian Journal of Horticulture, 63(4), 415-418.

2. Barreto, M. S., and Jagtap, K. B. (2006). Assessment of substrates for economical production of gerbera (Gerbera jamesonii F.) flowers under protected Cultivation. Journal of Ornamental Horticulture, 9(2), 136-138.

3. Bhatia, S., Gupta, Y. C., and Dhiman, S. R. (2004). Effect of growing media and fertilizers on growth and flowering carnation under protected condition. Journal of Ornamental Horticulture, 7(2), 174-178.

4. Chauhan, R. V., Varu, D. K., Kava, K. P., and Savaliya, V. M., (2014). Effect of different media on growth, flowering and cut flower yield of gerbera under protected condition. Asian Journal of Horticulture, 9(1), 228-231.

5. Dubey, R. K., Singh, S., Kukal, S. S., and Kalsi, H. S., (2013). Evaluation of different organic growing media for growth and flowering of petunia. Journal of Communication in Soil Sciences and Plant Analysis, 44(12), 1777-1785.

6. Evans, M. R., Konduru, S., and Stamps, R. H. (1996). Source variation in physical and chemical properties of coconut coir dust. Horticulture Sciences, 31, 965-967.

7. Gohil, P., Gohil, M., Rajatiya, J., Halepotara, F., Solanki, M., Malam, V. R., and Barad, R. (2018). Role of growing media for ornamental pot plants. International Journal of Pure and Applied Biosciences, 6(1), 1219-1224.

8. Ikram, S., Habib, U., and Khalid, N. (2012). Effect of different potting media on growth and vase life of tuberose. Pakistan Journal of Agricultural Sciences, 49(2), 121-125.

9. Jin, C. J., Suk, L. J., Myung, C. J., Choi, J. J., Lee, J. S., and Choi, J. M. (2002). Effect of physicochemical properties of growing media on growth, nutrient uptake and soil nutrient concentration in pot plant production of Asiatic hybrid lily cv. Orange Pixie. Journal of the Korean Society for Horticulture Sciences, 43(6), 747-753. 
10. Karthikeyan, S., and Jawaharlal, M. (2015). Optimization of growing media consortia for carnation. Asian Journal of Horticulture, 10(1), 17-25.

11. Khobragade, R. I., Damke, M. M., and Jadhao, B. J. (1997). Effect of planting time and spacing on growth, flowering and bulb production of Tuberose cv. Single. Acta Horticulture, 21, 44-47.

12. Kumar, S., Kumar, M., Malik, S., Singh, K., and Kumar, S. (2014). Evaluation of chrysanthemum cv. Tzvelev genotypes using morphological characters under climatic conditions of western UP. Annals of Horticulture, 7, 162-165.

13. Mehwish, K., Baloch, J. D., Waseem, K., Jilani, M. S., and Khan, M. Q. (2007). Effect of different growing media on the growth and development of dahlia (Dahlia pinnata). Pakistan Journal of Biology Sciences, 10(22), 4140-4143.

14. Mohapatra, A., Arora, J. S., and Sidhu, G. S. (2000). Evaluation of chrysanthemum varieties for pot culture. Journal of Ornamental Horticulture, 3(2), 79-82.

15. Naggar, A. H. E., and Nasharty, A. B. E. (2009). Effect of growing media and mineral fertilization on growth, flowering, bulbs productivity and chemical constituents of Hippeastrum vittatum. American.-Eurasian Journal of Agricultural and Environment Sciences, 6(3), 360-371.

16. Nair, S. A., and Bharathi, T. U. (2015). Influence of potting media composition on pot mum production. An International Quarterly Journal of Life Sciences, 10(1), 73-76.

17. Nazari, F., Farahmand, H., Khosh, K. M., and Salehi, H. (2011). Effects of coir as a component of potting media on growth, flowering and physiological characteristics of hyacinth (Hyacinthus orientalis L.) cv. Sonbol-e-Irani. International Journal of Agricultural and Food Sciences, 1, 34-38.

18. Nowak, J. S., and Strojny, Z. (2004). Effect of physical properties of organic growing medium on cut flower yield of gerbera. Fol. Uni. Agr. Stet. Agr, 94, 133-138.

19. Pal, A. L., and Biswas, B. (2005). Response of fertilizer on the growth and yield of tuberose (Polianthes tuberosa) cv. Calcutta single in the plants of West Bengal. Journal of International Academy, 9, 33-36.

20. Panse, V. G., and Sukhatme, P. V. (1964). Statistical methods of agricultural workers. Indian Council of Agricultural Research Publication, New Delhi. pp. 359-372.

21. Raj D. (2015). Floriculture at a glance. Kalyani Publishers, Ludhiana. pp. 83-85.

22. Rani, N., Kumar, R., and Dhatt, K. K. (2005). Effect of nitrogen level and growing media on growth, flowering and bulb production of Lilium cultivars. Journal of Ornamental Horticulture, 8(1), 36-40.

23. Shammy, F. H., Solaiman, A. H. M., Das, C., Islam, M. S., and Uddin, A. F. M. J. (2012). Growth and flowering characteristics of two potted gerbera (Gerbera Jamesonii) varieties. Jr. of Exp. Biosc, 3(1), 33 -36.

24. Singh, S. (2018). Effect of jeevamrit and different growing media on growth and flowering of gerbera (Gerbera jamesonii). M.Sc. (Hort.) Thesis, Department of Floriculture and Landscape Architecture, Dr. Yaswant Singh Parmar University of Horticulture and Forestry, Nauni, Solan.

25. Situmeang, Y. P., Arjana, G. M., and Siliani, K. (2017). Use of mulch and organic fertilizer on chrysanthemum. Sustainability Environment Agricultural Sciences, 1, 39-45.

26. Talukdar, M. C., Mahanta, S., Sharma, B., and Das, S. (2003). Extent of genetic variation for growth and floral characters in chrysanthemum cultivars under Assam conditions. Journal of Ornamental Horticulture, 6(3), 207-211. 
27. Turhan, H., Kahriman, F., Egesel, C. O., and Gul, M. K. (2007). The effect of different rooting media on the flowering and corm formation of saffron (Crocus sativus L.). African Journal of Biotechnology, 6, 2328-2332.

28. Warnita, Akhir, N., and Vina. (2017). Growth response of two varieties chrysanthemum on some media composition. International Journal on Advance Science Engineering Information Technology, 7(3), 928-935.

29. Yasmeen, S., Yonis, A., Rayit, A., and Raiz, A. (2012). Effect of different substrate growth and flowering of Carnation cv. Cauband Mixed. American.-Eurasian Journal of Agricultural and Environment Sciences, 12(2), 249-258.

Younis, A., Ahmad, M., Riaz, A., and Khan, M. A. (2008). Effect of different potting media on growth and flowering of Dahlia coccinia cv. Mignon. Acta Horticulture, 804, 191-196.

Tables

Table 1: Effect of Different Potting Media on Growth of Chrysanthemum CV. Haldighati.

\begin{tabular}{|l|c|c|c|c|c|}
\hline \multicolumn{1}{|c|}{ Treatments } & $\begin{array}{c}\text { Stem } \\
\text { Diameter } \\
(\mathbf{c m})\end{array}$ & $\begin{array}{c}\text { Plant } \\
\text { Spread } \\
(\mathbf{c m})\end{array}$ & $\begin{array}{c}\text { Fresh } \\
\text { Weight of } \\
\text { Leaf }(\mathbf{g})\end{array}$ & $\begin{array}{c}\text { Leaf } \\
\text { Biomass (g) }\end{array}$ & $\begin{array}{c}\text { Number of } \\
\text { Suckers Per } \\
\text { Plant }\end{array}$ \\
\hline \multicolumn{1}{|c|}{ Control: Garden Soil } & $\mathbf{0 . 2 8}$ & $\mathbf{8 . 3}$ & $\mathbf{0 . 1 2}$ & $\mathbf{2 . 1 0}$ & $\mathbf{0 . 4 4}$ \\
\hline Coco peat + Garden Soil (1:1) & 0.18 & 9.72 & 0.11 & 2.53 & 0.13 \\
\hline Coco peat + FYM + Garden Soil (2:1:1) & 0.32 & 12.13 & 0.2 & 4.34 & 1.55 \\
\hline Vermicompost + Garden Soil (1:1) & 0.3 & 10.44 & 0.1 & 2.86 & 0.55 \\
\hline Vermicompost + FYM + Garden soil (2:1:1) & 0.37 & 12.23 & 0.28 & 4.86 & 2.11 \\
\hline Perlite + Garden soil (1:1) & 0.34 & 10.33 & 0.18 & 3.34 & 1 \\
\hline Perlite + FYM + Garden soil (2:1:1) & 0.43 & 12.8 & 0.41 & 6.70 & 2.44 \\
\hline SEm \pm & 0.02 & 0.23 & 0.02 & 0.31 & 0.33 \\
\hline C. D. at 1\% & 0.10 & 0.99 & 0.08 & 1.31 & 1.43 \\
\hline
\end{tabular}

Table 2: Effect of Different Potting Media on Flowering of Chrysanthemum CV. Haldighati.

\begin{tabular}{|l|c|c|c|c|c|c|}
\hline \multicolumn{1}{|c|}{ Treatments } & $\begin{array}{c}\text { Days to } \\
\text { First } \\
\text { Colour } \\
\text { Shown }\end{array}$ & $\begin{array}{c}\text { Flower } \\
\text { Diamete } \\
\mathbf{r}(\mathbf{c m})\end{array}$ & $\begin{array}{c}\text { Number of Ray } \\
\text { Florets Per } \\
\text { Flower }\end{array}$ & $\begin{array}{c}\text { Length of } \\
\text { Ray Florets } \\
\text { (cm) }\end{array}$ & $\begin{array}{c}\text { Width of Ray } \\
\text { Florets }(\mathbf{c m})\end{array}$ & $\begin{array}{c}\text { Peduncl } \\
\text { e Length } \\
(\mathbf{c m})\end{array}$ \\
\hline Control: Garden Soil & 70.92 & 1.95 & 74.55 & 2.11 & 0.4 & 2.44 \\
\hline Coco peat + Garden Soil (1:1) & 67.44 & 2.22 & 75.11 & 2.17 & 0.43 & 2.89 \\
\hline $\begin{array}{l}\text { Coco peat + FYM + Garden } \\
\text { Soil (2:1:1) }\end{array}$ & 53.7 & 2.78 & 82.59 & 2.38 & 0.48 & 3.95 \\
\hline $\begin{array}{l}\text { Vermicompost + Garden Soil } \\
(1: 1)\end{array}$ & 65.18 & 2.53 & 76.15 & 2.27 & 0.44 & 3.19 \\
\hline $\begin{array}{l}\text { Vermicompost + FYM + } \\
\text { Garden soil (2:1:1) }\end{array}$ & 53.59 & 2.89 & 83.55 & 2.57 & 0.53 & 4.66 \\
\hline Perlite + Garden soil (1:1) & 64.44 & 2.64 & 78.39 & 2.31 & 0.46 & 3.72 \\
\hline $\begin{array}{l}\text { Perlite + FYM + Garden soil } \\
(2: 1: 1)\end{array}$ & 52.33 & 3.24 & 82.92 & 2.47 & 0.5 & 4.94 \\
\hline SEm + C. D. at 1 \% & 0.33 & 0.11 & 0.23 & 0.05 & 0.01 & 0.17 \\
\hline
\end{tabular}

